\title{
Statistical Approach of Nutrient Optimization for Microalgae Cultivation
}

\author{
Pichayatorn Bunkaew ${ }^{1}$ and Sasithorn Kongruang ${ }^{*}, 1$ \\ ${ }^{1}$ Bioprocess Engineering and Biotechnology, Department of Biotechnology, Faculty of Applied Science, King Mongkut's University \\ of Technology North Bangkok, Bangkok, Thailand
}

\begin{abstract}
The Plackett-Burman Design (PBD) was applied to study fresh water microalgae cultivation using Chlorella sp. TISTR 8411 to select the influential nutrient factors for biomass and lipid production. The PBD for 13 trials from 11 nutrient factors with 3 levels was studied in the mixotrophic cultivation at $28{ }^{\circ} \mathrm{C}$ under 16:8 light and dark photoperiods over 7 days of cultivation time. Two influential factors were chosen as glucose and cobalt chloride hexahydrate to further design via Box-Behnken Design (BBD) in order to optimize the cultivation of this microalgae for biodiesel production. The 17 trials of 3 factors and 3 levels of BBD experimental design technique were applied with varying factors of glucose $(20-40 \mathrm{~g} / \mathrm{L})$, cobalt chloride hexahydrate (0.01-0.04 mg/L) and light intensity (4,500-7,500 Lux) under 16:8 light and dark photoperiods over 7 days of cultivation time at $28{ }^{\circ} \mathrm{C}$. Result showed that Chlorella sp. TISTR 8411 cultivation yield $0.52 \mathrm{~g} / \mathrm{L}$ biomass and $0.31 \mathrm{~g} / \mathrm{L}$ lipid production resulting in approximately $60 \%$ of lipid production when cultivated in $20.05 \mathrm{~g} / \mathrm{L}$ glucose, $0.04 \mathrm{mg} / \mathrm{L} \mathrm{CoCl}_{2} 6 \mathrm{H}_{2} \mathrm{O}$ under light intensity of 4,614 Lux with the supplementation of $4.38 \mathrm{~g} / \mathrm{L} \mathrm{NaHCO} 3$ coupled with $1 \mathrm{~g} / \mathrm{L}$ of both $\mathrm{NaNO}_{3}$ and $\mathrm{KH}_{2} \mathrm{PO}_{4}$. Under statically mixotrophic cultivation, result indicated that Chlorella sp. TISTR 8411 had potential to produce high lipid content for biodiesel application and biomass production for nutraceutical application. Further experiment with the longer cultivation period up to 2 weeks would implement not only for monitoring the growth kinetics but also evaluating the suitable type of fatty acid production.
\end{abstract}

\section{Introduction}

Chlorella is a unicellular green microalgae existing in both aquatic and terrestrial habitats. Its biomass consists of approximately $68 \%$ protein, $13 \%$ fat, $10 \%$ carbohydrates $6 \%$ ash and $3 \%$ moisture. This strain contains not only at least 18 amino acids mainly glutamic acid, aspartic acid, leucine, alanine, valine and arginine but also multivitamin such as $\mathrm{A}, \mathrm{B}_{1}, \mathrm{~B}_{6}, \mathrm{~B}_{12}, \mathrm{C}, \mathrm{E}, \mathrm{K}_{1}$, folic acid and pantothenic acid. Pigments in forms of chlorophylls, carotenes and lutein are also found in amount of 2,770, 77.9 and $220 \mathrm{mg} / 100$ g-dry weight. Many minerals in forms of potassium, calcium, magnesium and iron are also included [1].

When these Chorella sp. strains were grown under favorable or stress culture conditions, the successfully biomass cultivation under mixotrophically attracts many health food and feed because of the capability of accumulating as high as $60 \%(\mathrm{w} / \mathrm{w}$, on dry-weight basis) oil within cells. The prospect of gaining high biomass concentration, different biochemical of choice and high biomass yield conversion is appealing to the application of mixotrophic cultures for commercial production. [28]. Previously, effects of media compositions on biomass and lipid accumulation of the isolate Chlorella $s p$. TISTR 8990 were investigated under PBD with mixotrophic cultivation conditions. Under this experimental design there were 15 different runs with ten factors-yeast extract, $\mathrm{KH}_{2} \mathrm{PO}_{4}, \mathrm{MgSO}_{4}, \mathrm{FeSO}_{4}, \mathrm{MnCl}_{2}$,
$\mathrm{CuSO}_{4}, \mathrm{Na}_{2} \mathrm{MoO}_{4}, \mathrm{H}_{3} \mathrm{BO}_{3}, \mathrm{ZnSO}_{4}$ and $\mathrm{pH}$ had been reported [7].

The lipids and fatty acids of this species have already been investigated and reported that mostly the major lipids found in this strain contain $\mathrm{C} 16$ and $\mathrm{C} 18$ fatty acyl groups, including C16:0, C16:2, C18:1, C18:2 and C18:3 [9-11]. However, the lipid productivity varies significantly among species [12]. In terms of food and feed applications, this microalgae grown under specific conditions can be used to produce compounds with nutritional benefits to human health such as carotenoids, $\beta$-carotene, neoxanthin, astaxanthin, sulphated polysaccharide $\beta-(1,3)$-glucan, recombinant proteins, methylcobalamin (vitamin $\mathrm{B}_{12}$ ), antioxidant and anti-inflammatory as anticancer peptides [13-17]. Moreover, the lipid content contained in this oleaginous microalgae accelerates the further green algae research on the bulk of their fatty acids as saturated and unsaturated $\mathrm{C} 18$, a composition similar to that of vegetable oils. Especially on a freshwater, fast-growing green alga Chorella vulgaris, has different lipid production capabilities (50\% of dry weight) under natural conditions [18]. Its mixotrophic growth modes with the different kinds of major and minor nutrient sources and development of cultivation designs for application of a renewable diesel for biorefinery have been investigated [19-21].

A number of factors is involved in the economically feasible culturing of microalgae such as nutrient 
availability, optimum light and temperature leading to yield high lipid content and growth rate [22].

For Chlorella $s p$. TISTR 8411 , there is absolutely no research that investigate this strain. To address these issues associated with the cultivation of this freshwater microalga Chlorella sp. TISTR 8411 as a new screening species in culture collection. This present paper was studied to identify and evaluate the nutrient cultivation effect on pure culture of Chlorella sp. TISTR 8411 designed for chosen the necessary nutrient for cultivation using (PBD) statistical experiment. The optimized range of the selected parameters screened by PBD were further optimization using Box-Benhken Design (BBD) of response surface mythology were investigated.

\section{Materials and methods}

\subsection{Microalgae strain and growth media}

Chlorella sp. TISTR 8411 from Culture Collection of Thailand Institute of Scientific and Technological Research. This strain was grown in mixotrophic condition with modified Tris-Acetate-Phosphate, TAP (Phytotech Lab, U.S.) at recommend doses (3.17 g/L, pH 7) coupled with of both $3 \mathrm{~g} / \mathrm{L}$ glucose and sodium bicarbonate. The cultivation at $28^{\circ} \mathrm{C}$ with $6,000 \mathrm{Lux}$ of light intensity. Single colony were observed in TAP agar and microscopically photograph with $10 \mathrm{X}$ amplification.

Initial cell concentrations of Chlorella $s p$. TISTR 8411 were determined by hemocytometer at $2.5 \times 10^{7}$ cells $/ \mathrm{mL}$ equivalent to the absorbance $680 \mathrm{~nm}$ at $2.5 \mathrm{AU}$ by using a UV/Visible spectrophotometer (Jenway 7200, UK). This inoculum number was maintained to all the runs.

\subsection{Inoculum preparation}

A $100 \mathrm{~mL}$ of inoculum was prepared in TAP medium, then incubated at room temperature at $28^{\circ} \mathrm{C}$ with $36 \mathrm{~W}$ cool white lights (Phillips, China). This culture was grown mixotrophically under 16:8 light and dark photoperiods at room temperature for 4 days. During the light period, the light intensity at the surface was 6,000 Lux. The initial cell density at $2.5 \times 10^{7}$ cells $/ \mathrm{mL}$ was inoculated to the rectangular vessels for 7 days as a batch culture in the PBD. Samples were collected from each batch to measure the biomass concentration and lipid content after day 7 cultivation period.

\subsection{Analytical methods}

\subsubsection{Biomass concentration}

For dry cell weight of the Chlorella sp. TISTR 8411, 150 $\mathrm{mL}$ of the culture broth were used in this study. The biomass concentrations were determined by the dry cell weight determination after centrifugation at $3,800 \mathrm{rpm}$ for $20 \mathrm{~min}$. After washing twice with distilled water, cell pellet was dried in freeze dryer at $0.120 \mathrm{mbar},-50^{\circ} \mathrm{C}$ for 2 days.

\subsubsection{Total lipid concentration}

The total lipid aliquots were extracted from lyophilized biomass, then the total lipid concentrations were determined by a single-step modified method according to Axelsson et. al. 2014 with a mixture of chloroform: methanol $(1: 2 \mathrm{v} / \mathrm{v})$ during the application of $90 \mathrm{~min}$ in a sonicator bath at $20 \mathrm{kHz}, 60 \mathrm{~W}$. A $0.73 \% \mathrm{NaCl}$ water solution was then added to 2:1:0.8 system of chloroform: methanol: water $(\mathrm{v} / \mathrm{v} / \mathrm{v})$ in duplicate for the extraction of the algae until cell color turned whitish. The extracted total lipid was centrifuged to obtain a clear supernatant and the solvent was removed by hot air oven drying at $70^{\circ} \mathrm{C}$ until a dry lipid was obtained. The total lipids were measure gravimetrically and the lipid contents were estimated according to PBD of the twice of triplicate data in each experimental run.

\subsection{Experimental design}

The PBD was used for evaluation the influential nutrient factors for biomass and lipid production. The selected nutrient factors were then chosen to further BBD.

\subsubsection{The influential nutrient factors $P B D$}

The PBD consisted of 11 factors (A-K). Factors for PBD were experimented with the concentrations in $\mathrm{g} / \mathrm{L}$ of $(\mathrm{A})$ glucose; 20-30, (B) $\mathrm{NaHCO}_{3} ; 1.5-6.0$, (C) $\mathrm{KH}_{2} \mathrm{PO}_{4} ; 0.85-$ 3.4, (D) $\mathrm{KNO}_{3}$; 0.25-1.0 (E) $\mathrm{NaNO}_{3} ; 0.25-1.0$ (F) yeast extract; $0.2-0.4$ and the concentrations $\mathrm{mg} / \mathrm{L}$ of $(\mathrm{G})$ $\mathrm{Na}_{2} \mathrm{MoO}_{4} 2 \mathrm{H}_{2} \mathrm{O} ; 0.03$ - $1.0(\mathrm{H}) \mathrm{MnCl}_{2} 4 \mathrm{H}_{2} \mathrm{O} ; 0.45-1.8$, (J) $\mathrm{CoCl}_{2} 6 \mathrm{H}_{2} \mathrm{O} ; 0.01-0.04$, (K) $\mathrm{MgSO}_{4} 7 \mathrm{H}_{2} \mathrm{O} ; 0.85-3.4$ and (L) $\mathrm{FeCL}_{3} 6 \mathrm{H}_{2} \mathrm{O} ; 0.5-1.5$. Each factor was tested at three levels as (-1), medium (0) and high (1). To identify these factors, the significant influential parameters on both of biomass and lipid production were chosen. Factors were carbon, nitrogen, phosphorus and trace elements $[4,23$, 24]. The 13 designed experiments were ran with each of $150 \mathrm{~mL}$ of $10 \%$ inoculum in $250 \mathrm{~mL}$ Erlenmeyer flasks containing $2.5 \times 10^{7}$ cells $/ \mathrm{mL}$. Culture mediums under static culture 6,000 Lux, 16:8 h light and dark photoperiod for 7 days (Fig. 1.) The biomass and total lipid concentration were estimated by harvesting $150 \mathrm{~mL}$ of 7 days of culture after that all experiments were measured gravimetrically.

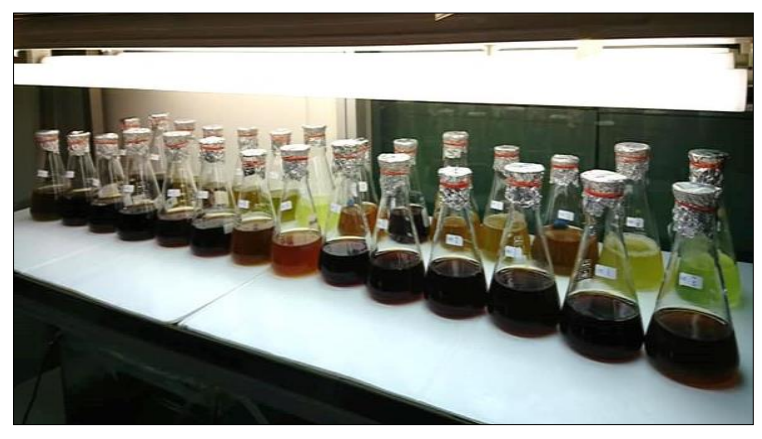

Fig. 1. Cultivation of Chlorella sp. TISTR 8411 


\subsubsection{Optimization and response surface methodology}

BBD was used to optimize the concentration of the nutrients factors selected, together with light intensity. 17 experiments was run and performed in $250 \mathrm{~mL}$ Erlenmeyer flasks containing $150 \mathrm{~mL}$ medium prepared together with a fixed concentration of $4.38 \mathrm{~g} / \mathrm{L} \mathrm{NaHCO}_{3}$ coupled with $1 \mathrm{~g} / \mathrm{L}$ of both $\mathrm{NaNO}_{3}$ and $\mathrm{KH}_{2} \mathrm{PO}_{4} 10 \%$ of inoculum containing $2.5 \times 10^{7}$ cell $/ \mathrm{mL}$ of cells was added to the $150 \mathrm{~mL}$ culture medium. The cultures were conducted under illumination 16:8 $\mathrm{h}$ light and dark photoperiods. The responses were estimated by harvesting $150 \mathrm{~mL}$ of 7 days cultivation time. All experiments were measured gravimetrically.

Optimization by response surface methodology was represented by quadratic model which was fitted via the response surface regression procedure, using the following second-order polynomial equation (1):

$$
=\beta_{0}+\sum \beta_{i} x_{i}+\sum \beta_{i i} x_{i 2}+\ldots \ldots . \sum \beta_{i j} x_{i} x_{j}
$$

Where $x_{1}, x_{2}$, and $x_{3}$, represent the coded level of the independent variables as described in table 2 and $\beta_{o} \beta_{i}$ and $\beta_{j}(i, j=1,2,3,4)$ are coefficient estimates, where, $\beta_{o}$ is the interception term, $\beta_{i}$ is the linear term, $\beta_{i i}$ is the interaction term. For the predicted responses, $\mathrm{y}_{1}$ stands for lipid content whereas, $y_{2}$ stands for biomass concentration. The accuracy and general ability of the above polynomial model could be evaluated by the coefficient of determination $\left(\mathrm{R}^{2}\right)$. Appropriate model significance was determined from the experiment data and was analyzed by using the statistical software, Design Expert version 11 (STAT-EASE Inc., Minneapolis, MN, USA) was used to fit the equations by regression analysis developed and also for the evaluation of the statistical significant of the equations. The three dimensional graphical representation response surface graphs were determined. The data were analyzed to estimate the coefficient of regression of experiment data. The response surface graph was analyzed by ANOVA to determine the significance of each term in the fitted equations and to estimate the goodness of fit in each case. The responses obtained were subjected to ANOVA and the significant variables $(\mathrm{p}<0.05)$ were optimized for their concentrations of biomass and total lipid concentration.

\section{Results and discussion}

\subsection{Morphological characteristics}

Chlorella sp. TISTR 8411 is a green eukaryotic microalgae belonging to the division Chlorophyta in the genus Chlorella, which explored since a well known $C$. vulgaris. It has utilized as many proposes, such as pharmaceuticals, animal feed, aquaculture, dyes and cosmetics. As shown in Fig. 2, Chlorella sp. TISTR 8411 showed approximately 10 $\mu \mathrm{m}$ in diameter of spherical shape without flagella and contained pigments chlorophyll-a and $-\mathrm{b}$ in its chloroplast as shown in Fig. 2. Generally, its cytoplasm contained the gel-like substance, which is composed of water, soluble proteins and minerals [18].
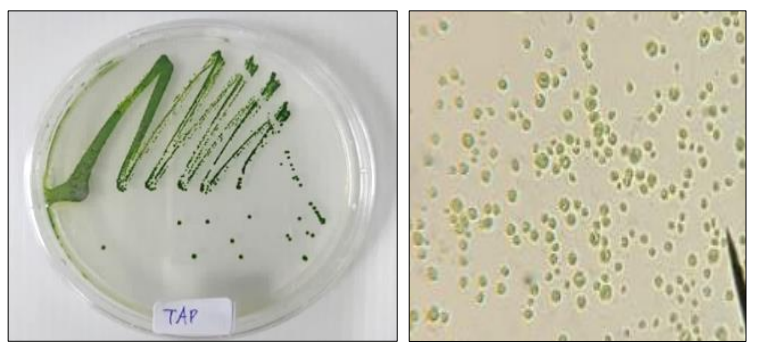

Fig. 2. Morphological structure of Chlorella sp. TISTR 8411 in TAP agar and under microscope with 10x amplification

During the exponential growth phase, this microalgae cell showed the dispersion in TAP medium and modified medium. The cells aggregation to lumps under static cultivation were observed after the cells reached the stationary phase. This observation might be associated with elevated $\mathrm{pH}$ due to $\mathrm{CO}_{2}$ level or the dissociation of sodium hydrogen carbonate, nitrate and phosphate assimilation [18].

\subsection{Screening of influential factors using PBD}

In this study, PBD was applied to study fresh water microalgae cultivation using Chlorella sp. TISTR 8411 to select the influential nutrient factors for biomass and lipid production. The PBD for 13 trials from 11 nutrients factors with 3 levels was studied in the mixotrophic cultivation at $28^{\circ} \mathrm{C}$ under $16: 8$ light and dark photoperiods over 7 days of cultivation time.

Under mixotrophic cultivation condition, results (obtained from the different parameters in three levels of the 11 factors) showed that glucose and $\mathrm{CoCl}_{2} \cdot 6 \mathrm{H}_{2} \mathrm{O}$ were determined as expected with high contribution parameters in biomass and lipid production (Table 1). The factors $\mathrm{NaHCO}_{3}, \mathrm{KH}_{2} \mathrm{PO}_{4}, \mathrm{KNO}_{3}$ and $\mathrm{CoCl}_{2} 6 \mathrm{H}_{2} \mathrm{O}$ had positive coefficients on biomass production of Chlorella sp. TISTR 8411. The other parameters had no significant effects on lipid production. In cases of lipid content, all parameters had negative effects.

The relationship between biomass concentration and lipid production in microalgae cell can be best described by the linear equations for biomass and lipid production. Results on PBD experiments were represented as these Equations (2), (3) under mixotrophic culture condition given as follows:

Biomass $(\mathrm{g} / \mathrm{L})=0.688-0.005$ glucose $+0.046 \mathrm{NaHCO}_{3}$ $+0.008 \mathrm{KH}_{2} \mathrm{PO}_{4}+0.021 \mathrm{KNO}_{3}-0.092 \mathrm{NaNO}_{3}-0.649$ yeast extract $-0.452 \mathrm{Na}_{2} \mathrm{MoO}_{4} 2 \mathrm{H}_{2} \mathrm{O}-0.082 \mathrm{MnCl}_{2} 4 \mathrm{H}_{2} \mathrm{O}$ $+0.894 \mathrm{CoCl}_{2} 6 \mathrm{H}_{2} \mathrm{O}-0.014 \mathrm{MgSO}_{4} 7 \mathrm{H}_{2} \mathrm{O}-0.01 \mathrm{FeCl}_{3} 6 \mathrm{H}_{2} \mathrm{O}$; $\mathrm{R}^{2}=0.967$

Lipid $(\mathrm{g} / \mathrm{L})=0.596-0.006$ glucose $-0.010 \mathrm{NaHCO}_{3}-$ $0.005 \mathrm{KH}_{2} \mathrm{PO}_{4}-0.021 \mathrm{KNO}_{3}-0.095 \mathrm{NaNO}_{3}-0.265$ yeast extract $-0.803 \mathrm{Na}_{2} \mathrm{MoO}_{4} 2 \mathrm{H}_{2} \mathrm{O}-0.005 \mathrm{MnCl}_{2} 4 \mathrm{H}_{2} \mathrm{O}$ - $2.903 \mathrm{CoCl}_{2} 6 \mathrm{H}_{2} \mathrm{O}-0.011 \mathrm{MgSO}_{4} 7 \mathrm{H}_{2} \mathrm{O}-0.054$ $\mathrm{FeCl}_{3} 6 \mathrm{H}_{2} \mathrm{O} ; \mathrm{R}^{2}=0.888$ 
According to the experimental results in table 1, the run 6 showed the maximum biomass concentration of 0.589 under $30 \mathrm{~g} / \mathrm{L}$ glucose, $6 \mathrm{~g} / \mathrm{L} \mathrm{NaHCO} 3,3.4 \mathrm{~g} / \mathrm{L}$ $\mathrm{KH}_{2} \mathrm{PO}_{4}, 0.25 \mathrm{~g} / \mathrm{L} \mathrm{KNO}_{3}, 0.25 \mathrm{~g} / \mathrm{L} \mathrm{NaNO}_{3}, 0.2 \mathrm{~g} / \mathrm{L}$ yeast extract, $0.1 \mathrm{mg} / \mathrm{L} \mathrm{Na} 2 \mathrm{MoO}_{4} 2 \mathrm{H}_{2} \mathrm{O}, 0.45 \mathrm{mg} / \mathrm{L} \mathrm{MnCl} 24 \mathrm{H}_{2} \mathrm{O}$, $0.04 \mathrm{mg} / \mathrm{L} \mathrm{CoCl} 26 \mathrm{H}_{2} \mathrm{O}, 3.4 \mathrm{mg} / \mathrm{L} \mathrm{MgSO}_{4} 7 \mathrm{H}_{2} \mathrm{O}$ and $0.5 \mathrm{mg} / \mathrm{L}$ $\mathrm{FeCl}_{3} 6 \mathrm{H}_{2} \mathrm{O}$.

Two influential factors were chosen as glucose and cobalt chloride hexahydrate to further design via BBD in order to optimize the cultivation of this microalga for biodiesel production because they gave the higher percentage contributions than other parameters. Moreover, perturbation graph effect showed curved shape. In terms of microalgae growth, glucose was considered as the major carbon source for supplement in mixotrophic cultivation. It also was the essential compound for photosynthesis for algae growth and reproduction. For mineral as $\mathrm{CoCl}_{2} 6 \mathrm{H}_{2} \mathrm{O}$, it was chosen among other trace elements because cobalt $\left(\mathrm{Co}^{2+}\right)$ might be attributed to the disruption of algal metabolism by inactivation of the photosynthetic machinery. Previously, investigation by Battah et. al., 2015 showed that the optimum concentration of cobalt nitrate appropriate for high lipid productivity was $2.5 \mu \mathrm{M}$ in order to gain a $22 \%$ increase in lipid of C. vulgaris [25].

\subsection{Effect of difference nutrient of sources for biomass and lipid production}

The 17 trials of 3 factors and 3 levels of BBD technique were applied with varying factors of glucose (20-40 $\mathrm{g} / \mathrm{L})$, cobalt choride hexahydrate (0.01-0.04 mg/L) and light intensity (4,500-7,500 Lux) under 16:8 light and dark photoperiods for 7 days of cultivation time at $28{ }^{\circ} \mathrm{C}$. Among 17 run of the $\mathrm{BBD}$, noticeable result from run no. 12 exhibited the highest biomass concentration $(0.547$ $\mathrm{g} / \mathrm{L}$ ) (Table 2). For this run, biomass production reached the highest value due to a high concentration of $20 \mathrm{~g} / \mathrm{L}$ glucose, $0.025 \mathrm{mg} / \mathrm{L}$ cobaltous chloride hexahydrate with 7,500 Lux under the constant value of $4.3 \mathrm{~g} / \mathrm{L}$ sodium bicarbonate coupled with $1 \mathrm{~g} / \mathrm{L}$ of potassium dihydrogen phosphate and potassium nitrate.

The determination coefficient $\mathrm{R}^{2}$ of biomass production was 0.943 , which indicated that this model adequately represented the relationship between chosen parameters. Analyses of variance of the biomass and lipid production for the models were shown in Table 3.

The regression mode for biomass was highly significant. Based on the significant of the regression coefficient of quadratic polynomial model, glucose was found to be the highly significant factor affecting the biomass yield $(\mathrm{p}=$ 0.00003). Light intensity was likely to contribute to some impact although it was not significant $(\mathrm{p}=0.08)$. The quadratic term $\left(\mathrm{x}_{3}^{2}\right)$, as light intensity, was significant ( $\mathrm{p}$ $=0.012$ ).

BBD was employed to understand the interactions between various nutritional and physical factors affecting biomass and lipid production. Therefore, Table 2 showed results of the responses, quadratic equation for biomass and lipid production from the analysis of variance test of significance as explained in Table 3, given as follows:

Biomass $(\mathrm{g} / \mathrm{L})=0.760+0.003$ glucose $+5.111 \mathrm{CoCl}_{2} 6 \mathrm{H}_{2} \mathrm{O}+$ 0.00001 light intensity - 0.111 glucose $\mathrm{CoCl}_{2} 6 \mathrm{H}_{2} \mathrm{O}$ $1.44 \cdot 10^{-6}$ glucose light intensity - 0.001 $\mathrm{CoCl}_{2} 6 \mathrm{H}_{2} \mathrm{O} \cdot$ light intensity +0.00003 glucose +33.333 $\mathrm{CoCl}_{2} 6 \mathrm{H}_{2} \mathrm{O}+0.2 \cdot 10^{-7}$ light $; \mathrm{R}=0.943$

Lipid $(\mathrm{g} / \mathrm{L})=-0.470+0.0003$ glucose +28.344 $\mathrm{CoCl}_{2} 6 \mathrm{H}_{2} \mathrm{O}+0.0001$ light -0.584 glucose $\cdot \mathrm{CoCl}_{2} 6 \mathrm{H}_{2} \mathrm{O}$ $+0.03 \cdot 10^{-5}$ glucose $\cdot$ light $-0.002 \mathrm{CoCl}_{2} 6 \mathrm{H}_{2} \mathrm{O} \cdot$ light + 0.0002 glucose $^{2}+16.667 \mathrm{CoCl}_{6} \mathrm{H}_{2} \mathrm{O}-0.001 \cdot 10^{-5}$ light ; R 0.87

The plots form perturbation graph showed the comparison of the effect from all the individual factors at a particular point in the design space. The responses were plotted by changing only one factor over its range, while keeping the other factors constant. The lines showing curves were the parameters showing significant effect on the responses (Fig. 3.) The glucose (A) had great effect on the biomass production.



a)

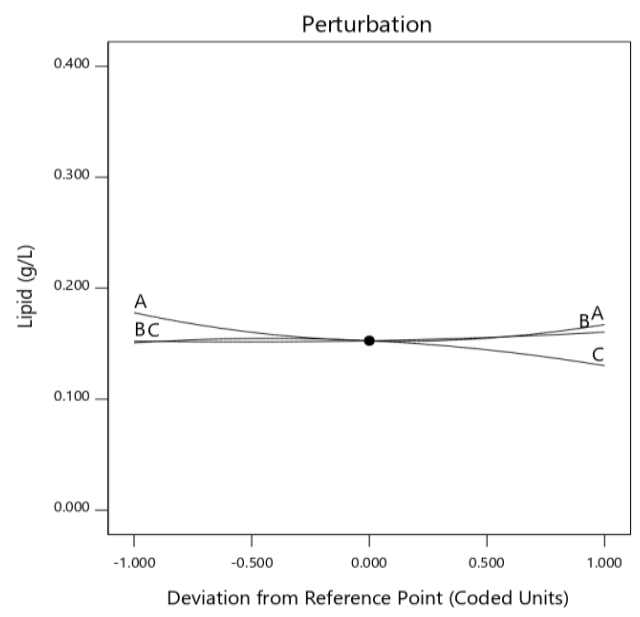

b)

Fig. 3. Perturbation graphs of variable affecting on a) biomass and b) lipid (A - glucose, $\mathrm{B}-\mathrm{CoCl}_{2} 6 \mathrm{H}_{2} \mathrm{O}$ and $\mathrm{C}$ - light intensity) $\left(\right.$ Coded $0=$ glucose $30 \mathrm{~g} / \mathrm{L}, \mathrm{CoCl}_{2} 6 \mathrm{H}_{2} \mathrm{O} 0.025 \mathrm{~g} / \mathrm{L}$ and 6,000 Lux) 
Table 1. Plackett-Burman Design with experimental values of biomass and lipid production in Chlorella sp. TISTR 8411.

\begin{tabular}{|c|c|c|c|c|c|c|c|c|c|c|c|c|c|}
\hline \multirow{3}{*}{ Run } & \multicolumn{11}{|c|}{ Factor } & \multicolumn{2}{|c|}{ Response } \\
\hline & $\mathbf{A}$ & B & $\mathrm{C}$ & D & $\mathbf{E}$ & $\mathbf{F}$ & $\mathbf{G}$ & H & $\mathbf{J}$ & K & $\mathbf{L}$ & \multirow{2}{*}{$\begin{array}{c}\text { Biomass } \\
\mathrm{g} / \mathrm{L}\end{array}$} & \multirow{2}{*}{$\begin{array}{c}\text { Lipid } \\
\text { g/L }\end{array}$} \\
\hline & \multicolumn{6}{|c|}{$g / L$} & \multicolumn{5}{|c|}{$\mathrm{mg} / \mathrm{L}$} & & \\
\hline 1 & -1 & 1 & 1 & -1 & 1 & 1 & 1 & -1 & -1 & -1 & 1 & $0.447 \pm 0.075$ & 0 \\
\hline 2 & 1 & -1 & 1 & 1 & 1 & -1 & -1 & -1 & 1 & -1 & 1 & $0.396 \pm 0.257$ & 0 \\
\hline 3 & -1 & -1 & 1 & -1 & 1 & 1 & -1 & 1 & 1 & 1 & -1 & $0.160 \pm 0.019$ & $0.032 \pm 0.003$ \\
\hline 4 & -1 & 1 & 1 & 1 & -1 & -1 & -1 & 1 & -1 & 1 & 1 & $0.543 \pm 0.061$ & $0.127 \pm 0.003$ \\
\hline 5 & -1 & -1 & -1 & -1 & -1 & -1 & -1 & -1 & -1 & -1 & -1 & $0.482 \pm 0.077$ & $0.321 \pm 0.010$ \\
\hline 6 & 1 & 1 & 1 & -1 & -1 & -1 & 1 & -1 & 1 & 1 & -1 & $0.589 \pm 0.123$ & 0 \\
\hline 7 & -1 & -1 & -1 & 1 & -1 & 1 & 1 & -1 & 1 & 1 & 1 & $0.296 \pm 0.189$ & 0 \\
\hline 8 & 1 & 1 & -1 & -1 & -1 & 1 & -1 & 1 & 1 & -1 & 1 & $0.398 \pm 0.067$ & 0 \\
\hline 9 & 1 & -1 & -1 & -1 & 1 & -1 & 1 & 1 & -1 & 1 & 1 & $0.151 \pm 0.097$ & $0.020 \pm 0.002$ \\
\hline 10 & 1 & -1 & 1 & 1 & -1 & 1 & 1 & 1 & -1 & -1 & -1 & $0.173 \pm 0.019$ & $0.092 \pm 0.008$ \\
\hline 11 & 0 & 0 & 0 & 0 & 0 & 0 & 0 & 0 & 0 & 0 & 0 & $0.280 \pm 0.113$ & 0.000 \\
\hline 12 & 1 & 1 & -1 & 1 & 1 & 1 & -1 & -1 & -1 & 1 & -1 & $0.398 \pm 0.064$ & $0.027 \pm 0.001$ \\
\hline 13 & -1 & 1 & -1 & 1 & 1 & -1 & 1 & 1 & 1 & -1 & -1 & $0.489 \pm 0.140$ & 0 \\
\hline
\end{tabular}

Table 2. Box-Behnken Design with experimental values of biomass and lipid production in Chlorella sp. TISTR 8411.

\begin{tabular}{|c|c|c|c|c|c|c|c|c|}
\hline \multirow[b]{2}{*}{ Run } & \multicolumn{3}{|c|}{ Factor } & \multicolumn{2}{|c|}{ Response } & \multirow[b]{2}{*}{$\begin{array}{c}\text { Biomass } \\
\text { productivity } \\
(\mathrm{g} / \mathrm{L} / \mathrm{d})\end{array}$} & \multirow[b]{2}{*}{$\begin{array}{l}\text { Lipid } \\
\text { productivity } \\
\text { (g/L/d) }\end{array}$} & \multirow[b]{2}{*}{$\begin{array}{c}\text { Lipid content } \\
(\%)\end{array}$} \\
\hline & $\begin{array}{c}x_{1}: \text { Glucose } \\
(\mathrm{g} / \mathrm{L})\end{array}$ & $\begin{array}{c}\mathrm{x}_{2}: \mathrm{CoCl}_{2} 6 \mathrm{H}_{2} \\
\mathrm{O}(\mathrm{g} / \mathrm{L})\end{array}$ & \begin{tabular}{|c|} 
X3:light \\
intensity \\
(Lux) \\
\end{tabular} & $\begin{array}{c}\text { Biomass } \\
(\mathrm{g} / \mathrm{L})\end{array}$ & $\begin{array}{l}\text { Lipid } \\
\text { (g/L) }\end{array}$ & & & \\
\hline 1 & 0 & 0 & 0 & 0.407 & 0.122 & 0.058 & 0.017 & 30 \\
\hline 2 & -1 & -1 & 0 & 0.493 & 0.049 & 0.070 & 0.007 & 10 \\
\hline 3 & 0 & 0 & 0 & 0.427 & 0.192 & 0.061 & 0.027 & 45 \\
\hline 4 & 1 & 1 & 0 & 0.320 & 0.128 & 0.046 & 0.018 & 40 \\
\hline 5 & -1 & 1 & 0 & 0.507 & 0.304 & 0.072 & 0.043 & 60 \\
\hline 6 & 0 & -1 & -1 & 0.407 & 0.179 & 0.058 & 0.026 & 44 \\
\hline 7 & 0 & 1 & -1 & 0.447 & 0.201 & 0.064 & 0.029 & 45 \\
\hline 8 & 0 & 0 & 0 & 0.427 & 0.149 & 0.061 & 0.021 & 35 \\
\hline 9 & -1 & 0 & -1 & 0.500 & 0.150 & 0.071 & 0.02 & 30 \\
\hline 10 & 1 & 0 & -1 & 0.400 & 0.120 & 0.057 & 0.017 & 30 \\
\hline 11 & 0 & 1 & 1 & 0.480 & 0.024 & 0.069 & 0.003 & 5 \\
\hline 12 & -1 & 0 & 1 & 0.547 & 0.191 & 0.078 & 0.027 & 35 \\
\hline 13 & 0 & 0 & 0 & 0.420 & 0.126 & 0.060 & 0.018 & 30 \\
\hline 14 & 1 & 0 & 1 & 0.360 & 0.180 & 0.051 & 0.026 & 50 \\
\hline 15 & 0 & -1 & 1 & 0.493 & 0.173 & 0.070 & 0.025 & 35 \\
\hline 16 & 1 & -1 & 0 & 0.373 & 0.224 & 0.053 & 0.032 & 60 \\
\hline 17 & 0 & 0 & 0 & 0.387 & 0.174 & 0.055 & 0.025 & 45 \\
\hline
\end{tabular}

Table 3. ANOVA for biomass and lipid concentration under response surface quadratic model.

\begin{tabular}{|c|c|c|c|c|c|c|}
\hline \multirow{2}{*}{ Factor } & \multicolumn{2}{|c|}{ Sum of squares } & \multicolumn{2}{c|}{ F value } & \multicolumn{2}{c|}{ p-value } \\
\cline { 2 - 7 } & Biomass & Lipid & Biomass & Lipid & Biomass & Lipid \\
\hline model & 0.056 & 0.042 & 12.848 & 1.338 & $0.001^{*}$ & 0.358 \\
\hline $\mathrm{X}_{1}-$ glucose & 0.044 & 0.000 & 91.497 & 0.066 & $0.00003^{*}$ & 0.805 \\
\hline $\mathrm{x}_{2}-\mathrm{CoCl}_{2} 6 \mathrm{H}_{2} \mathrm{O}$ & 0.000 & 0.000 & 0.046 & 0.037 & 0.836 & 0.853 \\
\hline $\mathrm{x}_{3}-$ light intensity & 0.002 & 0.001 & 4.170 & 0.243 & 0.080 & 0.637 \\
\hline $\mathrm{X}_{1} \mathrm{X}_{2}$ & 0.001 & 0.031 & 2.310 & 8.903 & 0.172 & $0.020^{*}$ \\
\hline $\mathrm{X}_{1} \mathrm{X}_{3}$ & 0.002 & 0.000 & 3.904 & 0.025 & 0.089 & 0.878 \\
\hline $\mathrm{X}_{2} \mathrm{X}_{3}$ & 0.001 & 0.007 & 1.479 & 2.109 & 0.263 & 0.190 \\
\hline $\mathrm{X}_{1}$ & 0.000 & 0.002 & 0.055 & 0.484 & 0.822 & 0.509 \\
\hline $\mathrm{x}_{2}$ & 0.000 & 0.000 & 0.492 & 0.017 & 0.505 & 0.900 \\
\hline $\mathrm{X}_{3}$ & 0.005 & 0.001 & 11.241 & 0.183 & $0.012^{*}$ & 0.682 \\
\hline Residual & 0.003 & 0.024 & & & & \\
\hline Lack of Fit & 0.002 & 0.021 & 2.551 & 7.460 & 0.194 & 0.041 \\
\hline Pure Error & 0.001 & 0.004 & & & & \\
\hline Corrected Total & 0.059 & 0.066 & & & & \\
\hline
\end{tabular}

*Biomass: significance level at $95 \%$ 
The modified media in our experiment of this statistically mixotrophic cultivation were investigated as shown in Table 2. The highest biomass production was recorded in run 12 with $0.547 \mathrm{~g} / \mathrm{L}$. Optimization yielded $0.08 \mathrm{~g} / \mathrm{L} / \mathrm{d}$ lipid productivity with the maximum lipid percentage of $35 \%$ under the cultivation condition. Statistical significant was determined at the $95 \%$ of confidence interval. Three-dimensional response surfaces were plotted on the basis of the model equation to investigate the interactions among the parameters and to determine the optimum concentration of each factor for maximum response (Figs. 4. and 5.). As illustration in the graph of Fig. 4, the biomass increased as the decreasing glucose concentration in culture media. The higher light intensity from 6,000-7,500 Lux with the lower glucose concentration resulted in the increasing the biomass concentration (Fig. 5). However, results showed no contribution effect found in the decreasing concentration of glucose and the higher light intensity toward the increasing $\mathrm{CoCl}_{2} 6 \mathrm{H}_{2} \mathrm{O}$ concentration (Fig. 4 and 5). The optimization mixotrophic cultivation values obtained from this model were as follows: $20.05 \mathrm{~g} / \mathrm{L}$ glucose, $0.04 \mathrm{mg} / \mathrm{L} \mathrm{CoCl} 26 \mathrm{H}_{2} \mathrm{O}$ under light intensity of 4,614 Lux with the supplementation of $4.38 \mathrm{~g} / \mathrm{L}$ $\mathrm{NaHCO}_{3}$ coupled with $1 \mathrm{~g} / \mathrm{L}$ of both $\mathrm{NaNO}_{3}$ and $\mathrm{KH}_{2} \mathrm{PO}_{4}$, with the supplementation of $4.38 \mathrm{~g} / \mathrm{L} \mathrm{NaHCO}_{3}$ coupled with $1 \mathrm{~g} / \mathrm{L}$ of both $\mathrm{NaNO}_{3}$ and $\mathrm{KH}_{2} \mathrm{PO}_{4}$ for giving a maximum biomass and lipid production of 0.520 and $0.313 \mathrm{~g} / \mathrm{L}$, while the interaction between glucose and light intensity (Fig. 4b) showed the lower glucose with higher light intensity up to 7,500 Lux promoted the biomass production.

RSM plots of predicted lipid concentration in Chlorella $s p$. were shown in Fig 5a-c. The illustration in Fig. 5a showed that the lower concentration of glucose with high range of $\mathrm{CoCl}_{2} 6 \mathrm{H}_{2} \mathrm{O}$ promoted the lipid production. The same trend of contour graph of interaction between light intensity and glucose and $\mathrm{CoCl}_{2} 6 \mathrm{H}_{2} \mathrm{O}$ was found (Fig. 5. b, c). The highest values of lipid equivalent to $0.304 \mathrm{~g} / \mathrm{L}$ when grown in $20 \mathrm{~g} / \mathrm{L}$ glucose with light intensity at 4,509 Lux. For $0.04 \mathrm{mg} / \mathrm{L}$ $\mathrm{CoCl}_{2} 6 \mathrm{H}_{2} \mathrm{O}$ with $4,500 \mathrm{Lux}$, the lipid concentration was produced at $0.304 \mathrm{~g} / \mathrm{L}$.

Results were found that the amounts of biomass and total lipid concentration in static mixotropically cultivation were obtained at quite low level. The biomass and total lipid concentration observed was lower than of 4 and 10 times of previously report by Haque et. al., 2012, which reported biomass and total lipid concentration at 2.20 and $0.43 \mathrm{~g} / \mathrm{L}$, respectively. Our experiment, there were $0.899 \mathrm{~g} / \mathrm{L}$ biomass and $0.228 \mathrm{~g} / \mathrm{L}$ lipid concentration, respectively. Our report found biomass and lipid productivity 0.179 and $0.0456 \mathrm{~g} / \mathrm{L} / \mathrm{d}$. Moreover, Rattanapoltee et. al., 2014 reported that the biomass and total lipid concentration were higher than 2.4 times compared with our report, but lipid yields were the same.

The interaction between glucose and light intensity showed significant influential toward lipid production. The optimization condition, in Table 3, showed that the biomass and lipid productivity were in agreement with Lee et. al., 2016, which reported the optimum conditions for cultivation of Chlorella $s p$. in wastewater from pig farms under mixotrophic for 5 days with aeration rate of $1.6 \mathrm{~L} / \mathrm{min}$ at $25^{\circ} \mathrm{C}$. They also reported that biomass productivity was $0.079 \mathrm{mg} / \mathrm{L} /$ day with lipid content of $17 \%$ of dried cell weight (about $0.07 \mathrm{~g} / \mathrm{L}, 0.014 \mathrm{~g} / \mathrm{L} / \mathrm{d}$ ). Moreover, Mubarak et. al., 2018, reported that Chlorella pyrenoidosa was cultivated with Bold's Basal Medium (BBM), the lipid concentration was increased from $17 \%$ to $36 \%$ of dry cell weight $(0.009$ to $0.096 \mathrm{~g} / \mathrm{L})$. Whereas, biomass decreased from 0.15 to $0.03 \mathrm{~g} / \mathrm{L}$ when compared with modified BBM without nitrogen source. The results in our experiment found that obtained yielded was 2 times higher for biomass and 34 times higher for lipid concentration than that of Mubarak et. al. 2018. They reported only $36 \%$ of DCW, $0.009 \mathrm{~g} / \mathrm{L}$ when increase light intensity 1.7 times $(3,500$ to $6,000 \mathrm{Lux})$ [25].

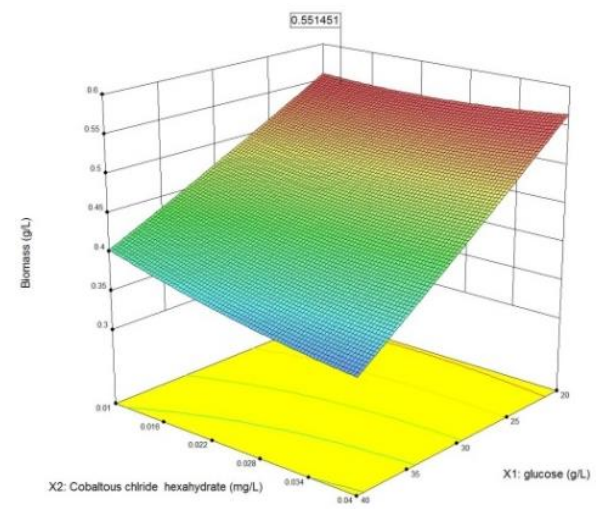

a)



b)

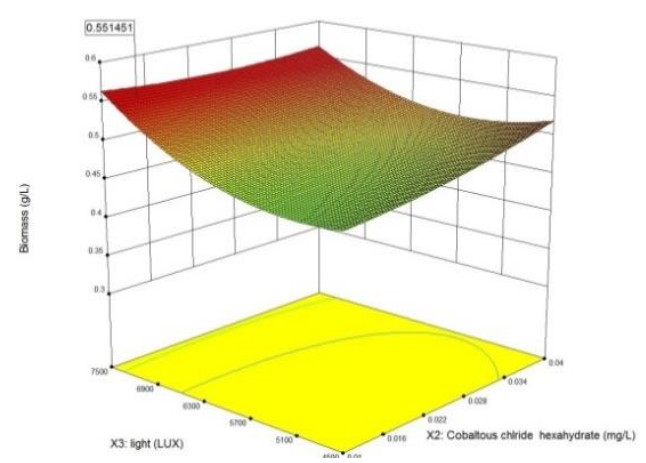

c)

Fig. 4. RSM of estimated biomass concentration in Chlorella $s p$. TISTR 8411 as functions of a) glucose and $\mathrm{CoCl}_{2} 6 \mathrm{H}_{2} \mathrm{O}$, b) glucose and light intensity and c) light intensity and $\mathrm{CoCl}_{2} 6 \mathrm{H}_{2} \mathrm{O}$ 




a)

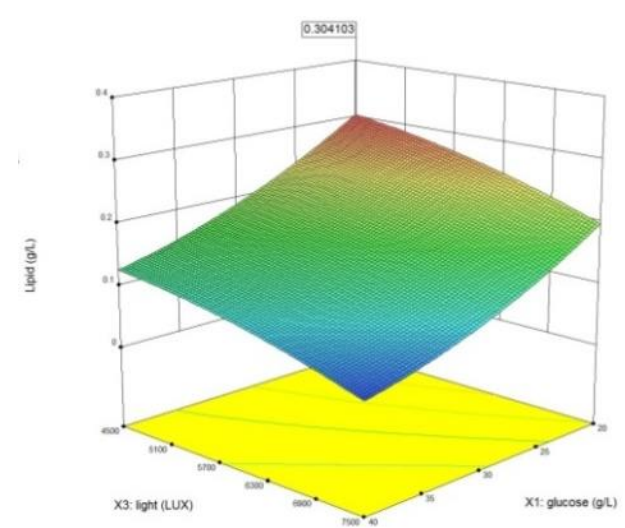

b)

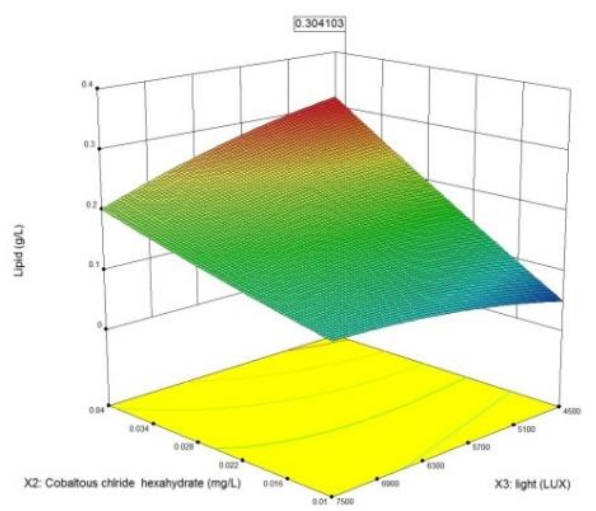

c)

Fig. 5. RSM plots of estimated lipid concentration in Chlorella $s p$. TISTR 8411 as functions of a) glucose, $\mathrm{CoCl}_{2} 6 \mathrm{H}_{2} \mathrm{O}$ b) glucose and light intensity and c) light intensity and $\mathrm{CoCl}_{2} 6 \mathrm{H}_{2} \mathrm{O}$.

Generally, the determination of initial sampling points play a pivotal role in the determination of strain selection as well as strain viability. The screening process should help to identify, purify and select lipid producing strains.

\subsection{Effect of major and trace elements}

The optimum level for this elements were 0.08 and $0.04 \mathrm{~g} / \mathrm{L} / \mathrm{d}$ in biomass and lipid productivity, respectively. Our good condition gained almost $60 \%$ of lipid percentage when these parameters were grown in
$20.05 \mathrm{~g} / \mathrm{L}$ glucose, $0.04 \mathrm{mg} / \mathrm{L} \mathrm{CoCl}_{2} 6 \mathrm{H}_{2} \mathrm{O}$ under light intensity of 4,614 Lux with the supplementation of 4.38 $\mathrm{g} / \mathrm{L} \mathrm{NaHCO}_{3}$ coupled with $1 \mathrm{~g} / \mathrm{L}$ of both $\mathrm{NaNO}_{3}$ and $\mathrm{KH}_{2} \mathrm{PO}_{4}$. Alternatively, there were many compounds as nitrogen sources $\left(\mathrm{KNO}_{3}, \mathrm{NaNO}_{3}, \mathrm{NH}_{4} \mathrm{NO}_{3}\right)$ that could be used, and many sources of phosphate $\left(\mathrm{KH}_{2} \mathrm{PO}_{4}\right.$, $\mathrm{NaH}_{2} \mathrm{PO}_{4} \cdot 2 \mathrm{H}_{2} \mathrm{O}$ ). Limitation of these key nutrients may resulted in negative shifts to the metabolic pathway of the organism $[25,27]$. Nitrogen and phosphorus starvation led to the lipid metabolism from membrane lipid synthesis to neutral lipid storage. This, in turn, increases the total lipid content of green algae.

Many trace elements were important in enzymes reactions and for biosynthesis of many compounds. For this investigation, cobalt was essential for vitamin $B_{12}$ production. Rachlin and Grosso (1993) reported that C. vulgaris had a great resistance to $\mathrm{Co}^{2+}$, and that toxic effects of $\mathrm{Co}^{2+}$ were recorded at very high concentrations. Moreover, Price and Morel (1990) concluded that the growth promotion at low $\mathrm{Co}^{2+}$ concentrations may be due to $\mathrm{Co}^{2+}$ substitution for $\mathrm{Zn}^{2+}$ in some metalloenzymes. For molybdenum $\left(\mathrm{Na}_{2} \mathrm{MoO}_{4} 2 \mathrm{H}_{2} \mathrm{O}\right)$ enzymes catalyze basic metabolic reactions in the nitrogen, sulfur, and carbon cycles. The molybdenum was associated with the heterocyclic pterin derivative (molybdopterin) that contained a mononucleate center coordinating to the thiols of the cofactor [28]. Another trace element was manganese $\left(\mathrm{MnCl}_{2} 4 \mathrm{H}_{2} \mathrm{O}\right)$, which was an essential constituent of a number of metalloenzymes, protein and vitamin complexes that perform key roles in algal metabolism. For magnesium $\left(\mathrm{MgCl}_{2} 6 \mathrm{H}_{2} \mathrm{O}\right)$, it was important trace element as essential $\mathrm{Co}^{+2}$ factor for enzymes catalyzing phosphorylation of proteins. Typically, they used magnesium chelates of ATP as cosubstrate. The bound $\mathrm{Mg}^{2+}$ served to facilitate nucleophilic attack at the $\mathrm{g}$ phosphate of the ATP substrate. Moreover, phosphate and phosphoryl transfer reactions require $\mathrm{Mg}^{2+}$ as an essential cofactor [29]. In chlorophyll molecules of photosynthetic reaction centers, magnesium ions were coordinated in aterrapyrrole ring system and to an axial $\mathrm{N}$-histidin, O-aspartate, O-formyl-methionin, O-leucin, or water as ligands. Lastly, iron $\left(\mathrm{FeCl}_{3} 6 \mathrm{H}_{2} \mathrm{O}\right)$ was metal present in normal growth and function of photosynthesis and respiration in algae [25-35].

\section{Conclusions}

Result showed that Chlorella sp. TISTR 8411 cultivation yield $0.520 \mathrm{~g} / \mathrm{L}$ biomass and $0.313 \mathrm{~g} / \mathrm{L}$ lipid production under $20.05 \mathrm{~g} / \mathrm{L}$ glucose, $0.04 \mathrm{mg} / \mathrm{L} \mathrm{CoCl}_{2} 6 \mathrm{H}_{2} \mathrm{O}$ under light intensity of 4,614 Lux with the supplementation of $4.38 \mathrm{~g} / \mathrm{L} \mathrm{NaHCO}$ coupled with $1 \mathrm{~g} / \mathrm{L}$ of both $\mathrm{NaNO}_{3}$ and $\mathrm{KH}_{2} \mathrm{PO}_{4}$. Results also indicated that under mixotropic cultivation conditions had a great potential for lipid production for biodiesel application. Further experiment with the longer cultivation period up to 2 weeks would require not only monitoring the growth kinetics but also capacity of lipid production and type of fatty acid production. Mixotrophic cultivation was analyzed in order to identify strategic planning for culture in 
laboratory scale bioreactor for improving biomass and in order to monitoring and checking the feasibility to scale up in pilot scale.

Acknowledge: The authors would like to thank National Science and Technology Development Agency for the financial support under Science, Technology Engineering and Mathematics for research and development for industry.

\section{References}

1. J. Liu, Q. Hu. Chlorella: Industrial Production of Cell Mass and Chemicals (2013)

2. P. Rattanapoltee, P. Kaewkannetra, Energy 78 (2014)

3. Z.Y. Liu, G.C. Wang, B.C. Zhou, Bioresour. Technol. (2008)

4. M.A. haque, P. bangrak, S. sirisansaneeyakul, Wanna choorit, Walailak J. Sci. \& Tech. 9 (2012)

5. D. Jaina, S.S. Ghonsea, T. Trivedia, G.L. Fernandesa, L.D. Menezesa, S.R. Damarea, S.S. Mamathaa, S. Kumarb, V. Guptaa, Bioresour. Technol. 273 (2019)

6. A.K. Patel, J.M. Joun, M.E. Hong, S.J. Sim, Bioresour. Technol. 282 (2019)

7. X. Deng, B. Chen, C. Xue, D. Li, X. Hu, K. Gao, Bioresour. Technol. 273 (2019)

8. F. Gaoa, H.L. Yang, C. Lia, Y.Y. Penga, M.M. Lua, W.H. Jina, J.J. Baoc, Y.M. Guoc, Bioresour. Technol. 282 (2019)

9. T. Trivedi, D. Jain, N.S.S. Mulla, S.S. Mamatha, S.R. Damare, R.A. Sreepada, S. Kumar, V. Gupta, Renew Energy 139 (2019)

10. N.T.L. Chi, P.A. Duc, T. Mathimani, A. Pugazhendhi, ISBAB. 17 (2019)

11. E. Sarayloo, S. Simsek, Y.S. Unlu, G. Cevahir, C. Erkey, I.H. Kavakli, Bioresour. Technol. 250 (2018)

12. M.K. Enamalaa, S. Enamalab, M. Chavalic, J. Donepudid, R. Yadavallie, B. Kolapallia, T.V. Aradhyulaf, J. Velpurig, C. Kuppamh, Renew. Sust. Energ. Rev. 94 (2018)

13. T. Lafarga, Algal Res. 41 (2019)

14. C. Galasso, A. Gentile, I. Orefice, A. Ianora, A. Bruno, D. M. Noonan, C. Sansone, A. Albini, C. Brunet, Nutrients 11 (2019)
15. J. Matos, C. Cardoso, N.M. Bandarra, C. Afonso, Food Funct. 8 (2017)

16. E. Talero, S.G. Mauriño, J.A. Román, A. Rodríguez-Luna, A. Alcaide, V. Motilva, Mar. Drugs 13 (2015)

17. G. L. Bhalamurugan, O. Valerie, L. Mark. Environ. Eng. Res. 23 (2018)

18. C. Safi, B. Zebib, O. Merah, P.Y. Pontalier, V.G. Carlos, Renew. Sustain. Energy Rev. 35 (2014).

19. A. Dash, R. Banerjee, Energy Convers. Manag. 164 (2018)

20. K. Bajwa, N.R. Bishnoi, A. Kirrolia, S. Gupta, S.T. Selvan, Appl. Water Sci. (2019)

21. P. Binnal, P.N. Babu, S. Afr. J. Chem. Eng. 23 (2017)

22. M.I. Khan, J.H. Shin, J.D. Kim, Microb. Cell. Fact. 17 (2018)

23. H.P. Ratnapuram, S.S. Vutukuru, R. Yadavalli, Heliyon 4 (2018)

24. M. Ghafari, B. Rashidi, B.Z. Haznedaroglu, Biofuels 9 (2016)

25. J.W. Rachlin, A. Grosso, Arch. Environ. Con. Tox. 24 (1993)

26. N.M. Price, F.M.M. Morel, Nature 344 (1990)

27. M. Battah, E.A. Yassin, A. El-Fatah Abomohra, S. E. Ghany, A. Esmael, Ann. Microbiol. 65 (2015)

28. A. Juneja, R.M. Ceballos, G.S. Murthy, Energies 6 (2013)

29. M.K. Mandal, P. Saikia, N.K. Chanu, N. Chaurasia, Environ. Sci. Pollut. Res. Int. 26 (2019)

30. C. Kobkam, J. Tinoi, S. Kittiwachana, KMUTNB Int J Appli Sci Technol. 11 (2018)

31. M.D. Allen, J.A. Campo, J. Kropat, S.S. Merchant, Eukaryot. Cell 6 (2007)

32. M. Mubarak, A. Shaija, V. Suchithra, Waste Bimass Valori. 10 (2018)

33. T. Wuttilerts, S. Chulalaksananukul, P. Peerapongpipat, P. Suksommanat. Appl Sci Eng Prog. 12 (2019)

34. Q. Hu, Handbook of Microalgal: Culture: Biotechnology Applied Phycology (2004)

35. R. Hille, Trends Biochem. Sci. 27 (2002)

36. M. Axelsson, F. Gentili, PLoS One 9 (2014) 